\title{
Enhancing Iranian EFL In-Service Teachers' Self-Efficacy Beliefs for Technology Integration
}

\author{
Abdulsalam Rigi \\ Department of English Language, College of Basic Sciences, Zahedan Branch, Islamic Azad University, Zahedan, Iran \\ Email address: \\ rigisalam@gmail.com \\ To cite this article: \\ Abdulsalam Rigi. Enhencing Iranian Efl In-Service Teachers' Self-Efficacy Beliefs for Technology Integration. International Journal of \\ Language and Linguistics. Vol. 3, No. 5, 2015, pp. 307-312. doi: 10.11648/j.ij11.20150305.15
}

\begin{abstract}
In recent decades successful teachers' using technology in their classrooms has been the center of vigorous debates in the field of teacher education. The present study investigated the self-efficacy beliefs of Iranian EFL in-service English as a foreign language teachers' for technology integration. The study first explored the perceived self-efficacy beliefs for technology integration. Second, it investigated the factors that might influence the teachers' technology integration practices; as a result, whether there was a mismatch between the teachers' self-efficacy beliefs and their technology integration. The participant who took part in this research were 30 in-service English language teachers working in the high schools of Zahedan. The necessary information is collected via Self-efficacy for Technology Integration Scale. In the qualitative phase, structured interviews were conducted with 12 volunteer teachers of English. The findings indicated that the participants had high levels of perceived self-efficacy for technology integration. Further, the interview results explored external/environmental and personal factors affecting teachers' technology integration practices. The study specifically concluded that there was a mismatch between the teachers' perceived self-efficacy beliefs for technology integration and their actual practices in the classroom.
\end{abstract}

Keywords: In-Service Teacher, Self-Efficacy Beliefs, Technology Integration

\section{Introduction}

The factor of technology integration has gained much influence with the emergence of technological tools in educational areas. According to Cowan (2008), technology integration is not a choice but a must for the teachers, so having low level of desire to use technology just makes the condition worse. However, Ertmer (1999) refers the factors affecting teachers' technology integration practices as external (first-order) and internal (second-order) barriers. The former one refers to problems like lack of training, local support, insufficient access to technologies; whereas, the latter one indicates teacher beliefs, teacher self-efficacy and teacher attitudes. Bandura (1989) claims that "among the types of thoughts that affect action, none is more central or pervasive than people's judgments of their capabilities to exercise control over events that affect their lives" (p. 59).

The notion of self-efficacy lies at the center of social cognitive theory and it is defined as the "belief in one's capabilities to organize and execute the courses of action required to produce given attainments" (Bandura, 1997, p. 3).
By taking social cognitive theory into account, teacher selfefficacy might be identified as a teacher's beliefs in his/her capability to plan, arrange, and perform tasks which are necessary in order to achieve the educational goals (Skaalvik \& Skaalvik, 2010).

Research suggests that teacher self-efficacy affects the use of technology instruction in classroom, so Bandura (1997) evidently points the impact of teachers' efficacy beliefs on the implementation of educational technologies. Notably, Skoretz (2011) explains efficacy for technology integration as "the belief in one's capability to integrate technology effectively in teaching and learning" (p.10). In what follows, Kim, Kim, Spector and DeMeester (2013) signify the value of efficacy beliefs for technology integration by putting out that in the absence of self-efficacy beliefs for using any technological tool, a teacher will most probably not integrate that technology successfully into his/her teaching practices.

Specifically speaking, a study by Hall (2008) investigates the relationship between computer self-efficacy and the perceived technology integration for high school mathematics and science teachers. The main findings of the study show a significant relation between perceived self- 
efficacy for computers and technology integration. Further, $\mathrm{Kao}, \mathrm{Wu}$ and Tsai (2011) primarily investigated the correlation between internet self-efficacy and belief about web-based learning. The authors reached the finding that teachers who have stronger beliefs on the positive results of web-based learning and increased self-efficacy have a tendency to display higher motivation toward web-based professional development. Kemp (2002) emphasizes when the year of computer experience increases, so does the selfefficacy practices of teachers.

A survey of the field shows that there are many barriers for technology integration such as lack of technical support, slow connection, personality factors, training and experience, lack of administrative support, and curriculum integration difficulties (Akça-Saklavacı, 2010; Smarkola, 2008; Brinkerhoff, 2006; Akbaba-Altun, 2006). Namely, Smarkola (2008) investigates both prospective and in-service teachers' beliefs regarding their computer use and the study reveals limitations for teachers' computer applications some of which are equipment resources and personal support from school administrators. Acording to Akça-Saklavacı (2010) lack of time, lack of technical resources and support from directors are some of the barriers for teachers when they want to use internet in their teaching practices. Likewise, a study by Akbaba-Altun (2006) aimed to identify issues concerning computer technology integration into the education system of Turkey and the findings indicate the problems such as lack of technical support, lack of training for teachers, materials and assessment issues regarding curriculum. Notably, Brinkerhoff (2006) groups the barriers for technology integration into four named as resources, institutional and administrative support, training and experience and attitudinal or personality factors.

Recently, a great number of studies have examined selfefficacy with different purposes in local context basically from a prospective teacher perspective; for example, prospective science teachers' teaching self-efficacy (Senler \& Sungur, 2010), student teachers' self-efficacy beliefs for mathematical literacy (Arslan \& Yavuz, 2012), pre-service teachers' self-efficacy for developing educational software (Uzun, Özkılıç \& Şentürk, 2010), the influences of mentors and classroom teachers on prospective English language teachers' self-efficacy beliefs (Pekkanl1-Egel, 2009), preservice English teachers' self-efficacy and tendency for academic dishonesty (Eminoğlu-Küçüktepe, 2010) have been investigated.

Based on the literature above, it may be suggested that there is a scarce of research both in the area of in-service teacher concept and technology integration practices. To that end, this study aims to investigate teacher's self- efficacy from technology integration viewpoint. The study also intends to explore the factors involved in teachers' selfefficacy beliefs for technology integration. Therefore, the following research questions form the basis of this study:

1. What is the level of technology integration selfefficacy and perceived English proficiency in the current sample?
2. What are the factors influencing teachers' technology integration practices in the foreign language classroom?

\section{Method}

\subsection{Participants}

The participants $(\mathrm{N}=30)$ of this study were Iranian EFL in-service teachers' who work at high schools in Zahedan. Out of 30 teachers, 21 (almost 91\%) of them voluntarily participated in the study. $69(60.5 \%)$ of the participants were female and $45(39.5 \%)$ of them were male. With respect to the age of the participants, $97(85.1 \%)$ of them were between 25 and 40 years old. $12(10.5 \%)$ of the respondents were between 41 to 50 years old, and only $5(4.4 \%)$ of them were more than 50 years old. Specifically, of the 30 participants, a total of 12 participants volunteered to take part in the interview. Seven teachers out of twelve were female, five of them were male. Pseudonyms were given for the participants of the interview.

\subsection{The Instrument}

Self-efficacy for Technology Integration Scale (SETIS) adapted from Wang, Ertmer and Newby (2004) and English Proficiency Scale (Chacon, 2005) were used for the current study. The permission which was needed to use the inventory was taken via e-mail from the authors of SETIS. SETIS consists of 18 items to examine self-efficacy beliefs in two logical areas named as Addressing Students' Technological Needs and Technology Integration in Teaching. The participants were asked to read a statement and decide if they (1) strongly disagree, (2) disagree, (3) neither agree nor disagree, (4) agree, (5) strongly agree with each statement.

\subsection{Data Analysis}

The statistical package SPSS 21.0 was used to analyze the quantitative data. To answer the first research question, descriptive statistics were calculated for the whole scale of SETIS and English proficiency scale. The descriptive statistics for each factor of SETIS were also computed. Regarding the second research question, interview data were analyzed by forming themes and categories. First, the transcribed data was read to decide if the answer was positive or negative in nature, then the reason why it was negative was determined by reading the data once more. Last, keywords obtained from the analysis were grouped into categories based on the self-efficacy literature.

\section{Results and Discussion}

The first research question aimed to reveal the perceived self-efficacy beliefs of Iranian EFL in-service teachers both for technology integration and English proficiency. Table 1. Reports the means and standard deviations for SETIS and English Proficiency Scale. Mean and standard deviations for two factors of SETIS were also presented.

As is seen in the table above, teachers' level of perceived 
English Proficiency $(M=5.46)$ was higher than their level of self-efficacy for technology integration in general $(M=4.19)$. In a similar fashion, Lee (2009) denoted the crucial relation between English proficiency and self-efficacy for English teaching by noting that "improving one's English language proficiency can enhance English teaching-specific teacher efficacy or confidence" (p.404). That is, high levels of English proficiency may have a positive impact on teachingspecific efficacy such as technology integration. In addition, Altun-Yalçın, Kahraman and Abidin-Yılmaz (2011) investigated in-service teachers' level of self-efficacy for instructional technologies in primary school context. The findings indicated high levels of self-efficacy for instructional technologies.

Table 1. Descriptive statistics for efficacy and English proficiency variables $(N=114)$.

\begin{tabular}{|c|c|c|c|c|c|}
\hline & $\mathbf{n}$ & Min. & Max. & Mean & St. Dev \\
\hline $\begin{array}{l}\text { Whole Scale Mean for } \\
\text { Technology Integration Scale }\end{array}$ & 30 & 2.50 & 5.00 & 4.19 & .50 \\
\hline $\begin{array}{l}\text { Addressing Students' } \\
\text { Technological Needs }\end{array}$ & 30 & 3.93 & 4.25 & 4.15 & .052 \\
\hline $\begin{array}{l}\text { Technology Integration in } \\
\text { Teaching }\end{array}$ & 30 & 3.98 & 4.25 & 4.17 & .056 \\
\hline $\begin{array}{l}\text { Whole Scale Mean for English } \\
\text { Proficiency Scale }\end{array}$ & 30 & 5.00 & 5.59 & 5.46 & .12 \\
\hline
\end{tabular}

Interestingly, teachers' level of efficacy for Addressing
Students' Technological Needs $(M=4.15)$ was lower than their efficacy for Technology Integration in Teaching $(M=4.17)$. In practical terms, teachers had high levels of efficacy for Technology Integration in Teaching than Addressing Students' Technology Needs which might mean that even though the teachers felt confident in using technology on their own, they might have some problems when the students need them. On a similar line, AkçaSaklavac1 (2010) examined the personal, professional and instructional use of internet among EFL teachers in local context. The results signified higher levels of personal and professional use of internet than the instructional use.

The second research question tried to shed light on the factors that affect the participants' technology integration practices in EFL classroom. By analyzing the interview data, two main categories were formed named as external/ environmental factors and personal factors. Three main sub categories were identified for each category; that is, perceived student attitudes, available learning opportunities and existing barriers were formed the external/environmental factors. For personal factors, attitudes toward use of instructional technology, practices for technology integration and amount of time used for instructional technology were the sub categories. Table 2 indicates the codes and explanations for each factor.

Table 2. Codes and explanations for factors influencing technology integration.

\begin{tabular}{|c|c|}
\hline Code & Explanation \\
\hline Perceived student attitudes & It refers to teachers' perceptions and observations for students' attitudes and interest for instructional technologies \\
\hline Example & $\begin{array}{l}\text { "I observe that they are happy and as every student cannot reach that technology currently, they see it as a } \\
\text { privilege" (Fatma) }\end{array}$ \\
\hline Available learning opportunities & It refers to in-service courses, time spent for learning technology tools, help from experts and school administration \\
\hline Example & $\begin{array}{l}\text { "We attend courses intensively from morning until evening and we have } 5 \text { minutes break just for coffee or tea" } \\
\text { (Serkan) }\end{array}$ \\
\hline Existing barriers & $\begin{array}{l}\text { It refers to technical problems, infrastructure, and limitations from the authorities, students and problems with the } \\
\text { technology device. }\end{array}$ \\
\hline Example & "As the classes are crowded, managing both the students and technology is difficult" (Ilhan) \\
\hline $\begin{array}{l}\text { Attitudes toward use of instructional } \\
\text { technology }\end{array}$ & $\begin{array}{l}\text { It refers to teachers' personal desire, curiosity for using technology, the perceived ease and convenience of } \\
\text { technology, perceived benefits for students, content area focus, and time perception. }\end{array}$ \\
\hline Example & "For me it gets the courses more active, it is enjoyable and paying students'attention is fast" (Melda) \\
\hline Practices for technology integration & It refers to teachers actual practices and their suggestions for technology integration \\
\hline Example & "In the past listening was very time consuming and it was not enjoyable but we can do it now" (Seda) \\
\hline $\begin{array}{l}\text { Amount of time used for } \\
\text { instructional technology }\end{array}$ & It refers to teachers' frequency of using technology in their classes \\
\hline
\end{tabular}

Concerning perceived student attitudes, factors like the students' increased attention, interest, curiosity, eagerness, motivation and participation were noted as positive influence of technology devices. According to Smarkola (2008), teachers use the computers in the classroom to prepare their students for the real world. Likewise, Sugar, Crawley and Fine (2004) revealed the student benefit as the main reason why teachers adopt technology. By contrast, respondents made some negative comments regarding those devices such as losing attention, getting bored and becoming lazy. Using internet not for educational purposes but for entertaining was also signified by the teachers. Likewise, students' entertainment expectation and being too dependent on technology were noted as negative beliefs of teachers concerning technology adoption by Sugar et al. (2004).

With respect to the available learning opportunities, topics such as prior knowledge on how to use technological devices, personal belief in the benefits of technological device and appropriate course load were connoted as positive influences increasing teachers' available time to learn instructional technologies. Similarly, Edwards (2005) noted the knowledge of computer components and use as one of the key factors in technology integration. According to Ertmer, Ottenbreit-Leftwich and York (2006), "even when resources and time are limited, exemplary teachers achieve effective use, quite possibly because of their strong 
beliefs, personal visions, and commitment to using technology" (p.57). On the contrary, insufficient break time and intensive course load were noted as some of the negative factors influencing teachers' available time to learn instructional technology. Farah (2011) also claimed insufficient time to learn instructional technology at school because the teachers are busy with contacting parents and managing paperwork during break time. Further, the study by Al-Alwani (2005) signified busy schedules of teachers as a barrier to their technology integration practices.

The respondents emphasized some barriers for their technology integration practices some of which were lack of and/or insufficient internet access, low running speed, inefficacy of students to use technology, classroom management, electricity cut off, lack of virus protection, lack of expert and radiation. Accordingly, Akbaba-Altun (2006) claimed slow internet connection as one of the factors decreasing technology integration. According to Akça-Saklavacı (2010), teachers could not use internet in their instruction due mainly to the slow internet connection. Crucially, Walker and Shepard (2011) recommended flexibility in lesson plan in order to cope with electricity related problems.

Teachers' personal desire and curiosity, perceived ease and convenience of technology and perceived level of comfort with technology were notified as factors increasing teachers' positive attitudes toward technology. In addition, Pinner (2012) reported that teachers have an intrinsic motivation towards using computer assisted language learning (CALL) in their teaching practices. Even more important, perceived usefulness and ease of technology use on pre-service teachers' level of computer technology usage were emphasized by a few researchers (Smarkola, 2007; Ma, Anderson \& Streith, 2005). Concerning worries, participants noted many points such as personal inadequacy, feeling anxious on usage, radiation from the device, making students' place ineffective, classroom management and instant technical problems. In this regard, Wang et al. (2004) equated low level of self-efficacy for technology integration with a teacher's low level of self-confidence with respect to his/ her ability and eagerness to use computers in teaching.

Close to the end, interview data related to actual practices for technology integration and amount of time used for instructional technologies showed that most of the teachers did not prefer to use instructional technologies in every lesson. Rather, they either prefer to use it one lesson and not use it in the other one or they just use it for additional activities. With respect to the activities that were covered, visuals, songs, videos, power point, pre-made resources and so forth were noted. In a similar fashion, Chen (2008) studied Taiwanese high school teachers' beliefs and actual practices regarding technology integration and the results revealed inconsistency between the teachers' beliefs and their actual practices. In what follows, Johnson (2006) reported that although teachers had high level of computer self-efficacy, their actual level of technology integration to curriculum was low.

\section{Conclusion}

The main aim of this investigation was to reveal enhancing Iranian EFL in-service teachers' self-efficacy beliefs for technology integration; further, the factors influencing their technology integration practices were examined. The findings of the questionnaire signified that participants had high levels of perceived self-efficacy for technology integration. Second, the interview results indicated two main factors affecting teachers' technology integration practices named as external/environmental and personal. Regarding the external/environmental factors, perceived student attitudes, available learning opportunities and existing barriers to integrate technology were emerged. In addition, attitudes toward use of instructional technology, practices for technology integration and amount of time used for instructional technology were the sub categories for personal factors. All in all, the study specifically found out that even though the teachers had high levels of perceived self-efficacy for technology integration, there were many factors impacting their practices in the classroom; so to say, their actual practices may not be as high as they perceived.

Based on these findings, the study has some valuable implications for effective technology integration in teaching practices. To name a few, the extensive course load was underlined as a barrier for technology integration, and approximately 21-24 hours of course load were suggested as appropriate by the respondents. In addition, teachers' course schedule should be organized in a way to have time for learning instructional technology at school. Even more important, the students should also be trained to use the current technologies effectively in their learning practices. Last, it may be more fruitful to speak of the controversy between EFL teachers' perceived self-efficacy for technology integration and their actual practices. Specifically speaking, Kim et al. (2013) put forward many ways to change teacher beliefs some of which were positive experiences, observation and collaboration.

The present study has some limitations which need to be addressed in future research. First, the current study only examined the self-efficacy beliefs of high school teachers, so a further study may compare the self-efficacy beliefs of high school and elementary school teachers. Second, the context of this study was very limited as it only included the schools in Zahedan; so to say, a similar study may well be implemented with other EFL teachers in local context.

\section{References}

[1] Akbaba-Altun, S. (2006).Complexity of integrating computer technologies into education in Turkey. Educational Technology \& Society, 9(1), 176-187.

[2] Akça-Saklavacı, A. (2010). The use of the internet among EFL teachers at high schools in Eskişehir. Unpublished Master's Thesis, Eskişehir: Anadolu University Graduate School of Educational Sciences. 
[3] Al-Alwani, A. E. S. (2005). Barriers to integrating information technology in Saudi Arabia Science Education. Unpublished Doctoral Dissertation, Kansas: The University of Kansas Graduate School of Education.

[4] Altun-Yalçın, S., Kahraman, S. \& Abidin-Yılmaz, Z. (2011). Primary school teachers of instructional technologies selfefficacy levels. Procedia-Social and Behavioral Sciences, 28, 499-502.

[5] Arslan, C. \& Yavuz, G. (2012).A study on mathematical literacy self-efficacy beliefs of prospective teachers. ProcediaSocial and Behavioral Sciences, 46, 5622-5625.

[6] Bandura, A. (1989). Social cognitive theory. In R. Vasta (Ed.), Annals of child development.Vol.6.Six theories of child development (pp. 1-60). Greenwich, CT: JAI Press. (Retrieved February 8, 2013 from http://www.uky.edu/ eushe2/Bandura/Bandura1989ACD.pdf )

[7] Bandura, A. (1997). Self-Efficacy: The exercise of control. New York: Freeman.

[8] Brinkerhoff, J. (2006). Effects of a long-duration, professional development academy on technology skills, computer selfefficacy, and technology integration beliefs and practices. Journal of Research on Technology in Education, 39(1), 22-40.

[9] Chacon, T. C. (2005). Teacher perceived efficacy among EFL teachers in middle schools in Venezuela. Teaching and Teacher Education, 21(3), 257-272.

[10] Chen, C. (2008). Why do teachers not practice what they believe regarding technology integration? Journal of Educational Research, 102(1), 65-75.

[11] Cowan, J. E. (2008). Strategies for planning technologyenhanced learning experiences. The Clearing House, 82(2), 55-59.

[12] Edwards, S. (2005). Identifying the factors that influence computer use in the early childhood classroom. Australasian Journal of Educational Technology, 21(2), 192-210. (Retrieved May 2, 2013 fromhttp://www.ascilite.org.au/ajet/ajet21/edwards.html)

[13] Eminoğlu-Küçüktepe, S. (2010). A study on preservice English teachers' self-efficacy perceptions and tendency towards academic dishonesty. Procedia Social and Behavioral Sciences, 2, 4985-4990.

[14] Ertmer, P. A. (1999). Addressing first- and second-order barriers to change: Strategies for technology integration. Educational Technology Research and Development, 47(4), 47-61.

[15] Ertmer, P. A., Ottenbreit-Leftwich, A. \& York, C. S. (2006). Exemplary technology-using teachers: Perceptions of factors influencing success. Journal of Computing in Teacher Education, 23(2), 55-61.

[16] Farah, A. C. (2011). Factors influencing teachers' technology self-efficacy: A case study. Unpublished Doctoral Dissertation, Lynchburg, VA: Liberty University.

[17] Hall, B. C. (2008). Investigating the relationships among computer self-efficacy, professional development, teaching experience, and technology integration of teachers. Unpublished Doctoral Dissertation, Cincinnati, Ohio: University of Cincinnati the College of Education, Criminal Justice, and Human Services.

[18] Johnson, I. (2006). An investigation of the effects of the Georgia Framework for Integrating TECHnology (InTech) training program on teachers' computer self-efficacy and computer utilization. Unpublished Doctoral Dissertation, Florida: Nova Southeastern University Graduate School of Computer and Information Sciences.

[19] Kao, C-P., Wu, Y-T. \& Tsai, C-C. (2011). Elementary school teachers' motivation toward web-based professional development, and the relationship with internet self-efficacy and belief about web-based learning. Teaching and Teacher Education, 27, 406-415.

[20] Kemp, C. R. (2002). Urban school teachers' self-efficacy beliefs and practices, innovation practices, and related factors in integrating technology. Unpublished Doctoral Dissertation, Boston: University of Massachusetts (Retrieved November 28, 2012 from www.iup.edu/WorkArea/linkit.aspx?...id.)

[21] Kim, C., Kim, M. K., Lee, C., Spector, J. M. \& DeMeester, K. (2013).Teacher beliefs and technology integration. Teaching and Teacher Education, 29, 76-85.

[22] Lee, J-A. (2009). Teachers' sense of efficacy in teaching English, perceived English language proficiency, and attitudes toward the English language: A case of Korean public elementary school teachers. Unpublished Doctoral Dissertation, Columbus: Graduate School of the Ohio State University.

[23] Ma, W. W., Andersson, R. \& Streith, K. O. (2005).Examining user acceptance of computer technology: An empirical study of student teachers. Journal of Computer Assisted Learning, 21(6), 387-395.

[24] Pekkanl1-Egel, I. (2009). The prospective English language teacher's reflections of self efficacy. Procedia Social and Behavioral Sciences, 1, 1561-1567.

[25] Pinner, R. S. (2012). Teachers' attitudes and motivations for using CALL in and around the language classroom. Procedia, Social and Behavioral Sciences, 34, 188-192.

[26] Senler, B. \& Sungur, S. (2010). Pre-service science teachers' teaching self-efficacy: a case from Turkey. Procedia Social and Behavioral Sciences, 9, 771-775.

[27] Skaalvik, E. M. \& Skaalvik, S. (2010). Teacher self-efficacy and teacher burnout: A study of relations. Teaching and Teacher Education, 26, 1059-1069.

[28] Skoretz, Y. M. (2011). A study of the impact of a school-based job-embedded professional development program on elementary and middle school teacher efficacy for technology integration. Unpublished Doctoral Dissertation, West Virginia: Marshall University Graduate School of Education and Professional Development.

[29] Smarkola, C. (2007). Technology acceptance predictors among student teachers and experienced classroom teachers. Journal of Educational Computing Research, 37(1), 65-82.

[30] Smarkola, C. (2008). Efficacy of planned behavior model: Beliefs that contribute to computer usage intentions of student teachers and experienced teachers. Computers in Human Behavior, 24, 1196-1215.

[31] Sugar, W., Crawley, F., \& Fine, B. (2004). Examining teachers' decisions to adopt new technology. Educational Technology and Society, 7(4), 201-213.

[32] Uzun, A., Özkılıç, R. \& Şentürk, A. (2010). A case study: Self-efficacy beliefs of teacher candidates regarding developing educational software. Procedia Social and Behavioral Sciences, 2, 5001-5005. 
[33] Walker, L. R., \& Shepard, M. (2011).Phenomenological investigation of elementary school teachers who successfully integrated instructional technology into the curriculum. Journal of Educational Research and Practice, 1(1), 23-35.
[34] Wang, L., Ertmer, P. A., \& Newby, T. J. (2004). Increasing pre-service teachers' self-efficacy beliefs for technology integration. Journal of Research on Technology in Education, $36(3), 231-250$. 